\title{
Quantitative and Topographic Analysis by Immunohistochemical Expression of Ghrelin Gastric Cells in Patients with Morbid Obesity
}

This article was published in the following Dove Press journal: Diabetes, Metabolic Syndrome and Obesity: Targets and Therapy

\author{
David Parada $D^{1}$ \\ Karla B Peña $G^{\prime}$ \\ Margarida Vives ${ }^{2}$ \\ Alicia Molina ${ }^{2}$ \\ Emilio Mayayo ${ }^{3}$ \\ Frances Riu' \\ Fàtima Sabench ${ }^{2}$ \\ Daniel Del Castillo (iD ${ }^{2}$ \\ 'Pathology Service, University Hospital of \\ Sant Joan. Faculty of Medicine, IISPV, \\ "Rovira i Virgili" University, Reus, \\ Tarragona, Spain; ${ }^{2}$ Surgery Service, \\ University Hospital of Sant Joan, Faculty \\ of Medicine, IISPV, "Rovira i Virgili" \\ University, Reus, Tarragona, Spain; \\ ${ }^{3}$ Pathology Service, University Hospital of \\ Joan XXIII, Faculty of Medicine, IISPV, \\ "Rovira i Virgili" University, Reus, \\ Tarragona, Spain
}

Purpose: The cellular distribution of ghrelin positive cells is not well defined. The aim of the study is to quantify and determine the distribution of ghrelin cells in gastric mucosa in patients with morbid obesity and relate this finding to gender, comorbidities, gastritis, and plasmatic levels of acyl and desacylghrelin before and after laparoscopic sleeve gastrectomy. Patient and Methods: We performed a study on 61 patients with $\mathrm{BMI} \geq 50 \mathrm{~kg} / \mathrm{m}^{2}$ operated by laparoscopic sleeve gastrectomy. Three gastric regions were analyzed by histopathology and immunohistology. Blood sample was taken before surgery, and at 6 and 12 months postsurgery, to study the plasma levels of ghrelin isoforms.

Results: Ghrelin cells are present in all regions of the gastric mucosa, with a greater number in the body and the fundus. Difference was found in the antrum between male and female patients $(\mathrm{p}=0.018)$. Patients with arterial hypertension also showed a lower level of cells in antrum $(\mathrm{p}<0.05)$. Acylghrelin levels after surgery were significantly lower $(32.83+5.6 \mathrm{pg} / \mathrm{mL}$ to $10.09+11.8 \mathrm{pg} / \mathrm{mL}, \mathrm{p}<0.05)$. Values of desacylghrelin tended to decrease but no significant variation was observed $(207.4+39.3 \mathrm{pg} / \mathrm{mL}$ to $188.84+52.3 \mathrm{pg} / \mathrm{mL})$.

Conclusion: Our patients show ghrelin cells in all areas of the stomach. Gender, comorbidities, and gastritis are determinant on gastric ghrelin-producing cells distribution.

Keywords: ghrelin, cells, obesity, gastric, laparoscopic surgery

\section{Introduction}

Obesity is a public health problem in the world. It affects quality of life, increases the risk of illness, and raises health-care costs in countries around the world. ${ }^{1,2}$ In 1999, Kojima et $\mathrm{al}^{3}$ discovered that the gastric ghrelin is a ligand for the growth hormone secretagogue receptor. Several studies have shown that ghrelin has numerous physiological effects: for example, it regulates food intake, body weight, adiposity, and glucose metabolism; it modulates the systemic metabolism and improves cardiovascular functions such as vasodilatation and cardiac contractility. ${ }^{4-7}$ There are two forms of ghrelin: acylghrelin (AG) and desacylghrelin (DG). ${ }^{8} \mathrm{AG}$ has a short half-life, and once released, is converted to $\mathrm{DG} ;{ }^{9} \mathrm{AG}$ disappears more rapidly from plasma than $\mathrm{DG} .{ }^{10}$ These two isoforms have differential effects on tissues: while $A G$ is implicated in the control of food intake and evokes weight gain by hypothalamic actions, DG can participate in some of these processes, but its exact function is still unknown. ${ }^{11}$ Ghrelin O-acyltransferase (GOAT) is the enzyme responsible for the acylation process of ghrelin. ${ }^{12}$
Correspondence: Daniel Del Castillo Head Surgery Department, Hospital Universitari Sant Joan, Facultat de Medicina, U.R.V., Reus, Spain Email fatima.sabench@urv.cat 
Bariatric surgery has proven to be effective for weight reduction and resolving comorbidities in morbidly obese patients. ${ }^{13}$ However, there is no clear consensus as to effect of bariatric surgery on the circulating ghrelin levels. ${ }^{14}$ Laparoscopic sleeve gastrectomy (LSG) is a bariatric surgical technique of choice within the options for the treatment of morbid obesity and it is currently in first position in the global count of the almost 600,000 annual bariatric surgeries performed worldwide (46\%), surpassing Laparoscopic Roux-en-Y Gastric Bypass (40\%) for the first time since $2013 .{ }^{15}$ LSG leads to the physical loss of the main producer of ghrelin from the organism, which has traditionally been attributed to the oxyntic gastric mucosa. However, the distribution of ghrelin is not uniform, it varies between sexes and it does not correlate with its serum levels; all this can influence the surgical strategy and the posterior pathophysiological implications. ${ }^{16}$

The main objective of the study is to quantify and determine the topographic distribution of ghrelin cells (GhrC) in the gastric mucosa in patients with morbid obesity and relate this finding to gender, comorbidities, and the presence of gastritis. An additional aim is to analyze the plasmatic levels of AG and DG before and after surgery and their relation to the number of gastric cells.

\section{Materials and Methods}

We performed a prospective and descriptive cohort study on morbid obesity patients operated by LSG. Sixty-one patients from the external consultations of Bariatric Surgery of our hospital who had undergone LSG for morbid obesity. We perform this technique according to our hospital protocol in patients with a BMI greater than $50 \mathrm{Kg} / \mathrm{m} 2$ (which allows completing a second surgery if necessary in the future); It is also performed in patients with giant liver disease, chronic liver disease, or inability to access the inframesocolic compartment and who have a BMI less than $50 \mathrm{~kg} / \mathrm{m} 2$ (to avoid access problems or avoid worsening liver disease due to the malabsorptive component). Despite the exponential growth of the Sleeve gastrectomy in very diverse ranges of BMI, it is still a very safe option for superobese patients in terms of decreased surgical risk. ${ }^{17}$ Antrum, body, and fundus of each patient included in the study were analyzed by histopathology and immunohistology. Plasma levels of the two ghrelin isoforms were studied before surgery, and at 6 and 12 months after surgery. Before the surgery, patients underwent a gastric endoscopy with biopsy. The study protocol was reviewed and approved by the Ethics Committee of the Sant Joan University Hospital in Reus (registration number CEIC11-04-28/4PROJ3), and written informed consent was obtained from each subject in accordance with the 1964 Helsinki declaration and its subsequent amendments.

\section{Surgical Technique}

LSG was performed under general anesthesia with the patient in the Lloyd-Davies position. A five-port technique was used in all patients: the first $10-\mathrm{mm}$ midline trocar was inserted under direct optical control (Visiport, Covidien ${ }^{\circledR}$, USA). A $15-\mathrm{mm}$ trocar inserted into the right hypochondrium served to introduce the endostapler (4.8-mm staples) required for the first transections of the gastric antrum and was useful for extracting the resected stomach. The greater gastric curvature was then dissected, separating it from the gastroepiploic arcade of the greater omentum. Instruments for sealing and sectioning the tissues (LigaSure, Covidien ${ }^{\circledR}$ ) were used for this procedure. Dissection was continued to the His angle; freeing the posterior fundal region is extremely important to avoid leaving a residual pocket. In all cases, the gastric transection was performed under the guidance of a 38-Fr Faucher bougie. The distance from the pylorus to the first section point $(3 \mathrm{~cm})$ was measured intraoperatively with a ribbon. The suture line was reinforced using polycarbonate derivatives of polyglycolic acid (SEAMGUARD, W.L. Gore \& Associates ${ }^{\circledR}$, USA). Finally, a sub-hepatic Jackson-Pratt-type drain was placed along the suture. A methylene blue leak test was performed in all patients before the end of the surgery. In the surgical specimen, each gastric region was adequately referred by the surgeon in the operating room and sent to the pathology service for study.

\section{Histopathology and Immunohistology Examination}

At the pathology service, the stomach was opened by the greater curvature and fixed in formalin for $24 \mathrm{hr}$. After fixation, sections from the antrum, body, and fundus were taken according to the references and were embedded in paraffin, cut at $2 \mu \mathrm{m}$, and stained with hematoxylin and eosin. In addition, 2- $\mu \mathrm{m}$ sections were obtained and were placed in an automatic processor VENTANA ${ }^{\circledR}$ Benchmark ULTRA/LT immunohistochemistry, Ventana Medical Systems, USA, using the previously standardized protocol 
for ghrelin including detection kit and Optiview ${ }^{\circledR}$ DAB $\left(\right.$ VENTANA $\left.^{\circledR}\right)$. The primary anti-ghrelin antibody $(1: 600)$ (Phoenix Pharmaceutical, Inc) was incubated for $32 \mathrm{~min}$. Finally, the immunohistochemical sections were revealed with Diaminobenzidine, contrasted with Meyer's hematoxylin, and examined under an Olympus BX41 light microscope. The histopathological parameters of gastric biopsy were evaluated according to the Revised Sydney Classification to chronic inflammation. ${ }^{18}$

Quantitative study of GhrC: Quantification was carried out using a compatible HP Compaq 6000 Pro Mt personal computer. HP Compaq 6000 Pro Mt Intel ${ }^{\circledR}$ Core $^{\text {TM }} 2$ Duo PCE7500@2.936GHz CPU, 1.93GB RAM, Microsoft Windows XP Professional Version 2002 system, with an HP Compaq LA1951 LCD monitor on Intell Q45/Q43 Express Chipset, Olympus BX41 Microscope, Olympus camcorder SC30 model, and a 4Gbyte hard drive memory. The increase used for quantification of the GhrCs was 20x with a field diameter of $0.40 \mathrm{~mm}$. We used the program Cell B 3.3, Olympus Soft Imaging Solutions $\mathrm{GmbH}$ for direct quantification. GhrcCs were counted in 10 fields, representing a total area of $1.25 \mathrm{~mm}^{2}$. As inclusion criteria, all the cells that were positioned in the different sections were taken into account. A positive GhrC was considered when cytoplasmic labeling was obtained. The calculation was made by the average and the standard deviation obtained from the three gastric anatomical regions analyzed for each patient.

\section{Semi-Quantitative Study of GhrC}

For the semiquantitative analysis, a suitable section was considered when it was possible to evaluate the muscle of the submucosa. The distribution patterns of $\mathrm{GhrC}$ were categorized as follows: 1) Irregular: GhrC appeared at random in the mucosa. 2) Two-thirds distribution: GhrC in the lower two-thirds of the mucosa. 3) Lower third distribution: GhrC located in the lower third of the mucosa.

\section{Hormone Assays}

Blood samples were obtained in the morning after overnight fasting and placed in Vacutainer ${ }^{\circledR}$ EDTA-plasma tubes. The samples were promptly centrifuged at $3000 \mathrm{~g}$ for $15 \mathrm{~min}$ at $4^{\circ} \mathrm{C}$, and the plasma was stored at $-80^{\circ} \mathrm{C}$. Plasma concentrations of AG and DG were measured with an ELISA kit (Merck KGaA, Darmstadt, Germany) according to the manufacturer's instructions.

\section{Statistical Analysis}

For the calculation of the number of patients in the study, we used the formulas corresponding to the comparison of means and analysis for each of the main variables. The results from morphometric analysis are shown as mean \pm SD. Differences in results of ghrelin cells and clinical parameters were examined by a non-parametric MannWhitney test for two independent groups. The relationships between GhrC and clinic-pathological variables were examined by linear regression and Spearman correlation coefficient analyses. $p<0.05$ was considered statistically significant. All the analyses were performed using the program IBM.SPSS 23.

\section{Results}

\section{Clinical Findings}

Of the 61 patients included, 26.2\% (16) were males and $73.8 \%$ (45) females. The average BMI was $51.11 \mathrm{~kg} / \mathrm{m} 2$ (ranging from 38.13 to $65.01 \mathrm{~kg} / \mathrm{m} 2$ ). The average age was 51.08 years (ranging from 27 to 73 years old). Systemic arterial hypertension (SAH) was present in 59\% (36) cases. Type 2 Diabetes (T2DM) was present in $63.9 \%$ (39) patients. As high as $29.5 \%$ (18) patients showed both comorbidities. Previous Helicobacter pylori infection was present in $18.03 \%$ (11) patients. Patients with intestinal metaplasia undergo endoscopic follow-up at 18 months after surgery and subsequently according to findings found in the respective biopsies.

\section{Histopathological Findings}

Chronic gastritis was present in $88.5 \%$ of patients. The gastritis was present in all gastric regions in $81.48 \%$ of cases and the severity was cataloged as mild. Intestinal metaplasia was present in $8.5 \%$ of patients. No Helicobacter pylori infection was detected into gastric specimen.

\section{Quantification and Gastric Topography of GhrC}

Immunohistochemical study of $\mathrm{GhrC}$ showed a total of $786.30 \pm 465.2$ cells/10HPF. The immunoreaction was granular, and the cells had a variable morphology, from cubic to slightly elongated. GhrC was isolated or in pairs, although larger groups of cells (more than 4 cells) were observed (Figure 1). In the antrum, $217.28+196.6$ cells/10HPF were quantified, in the body was $292.18+231.5$ cells/10HPF, and $276.84+166.2$ cells/10HPF in the fundus. Statistical analysis 

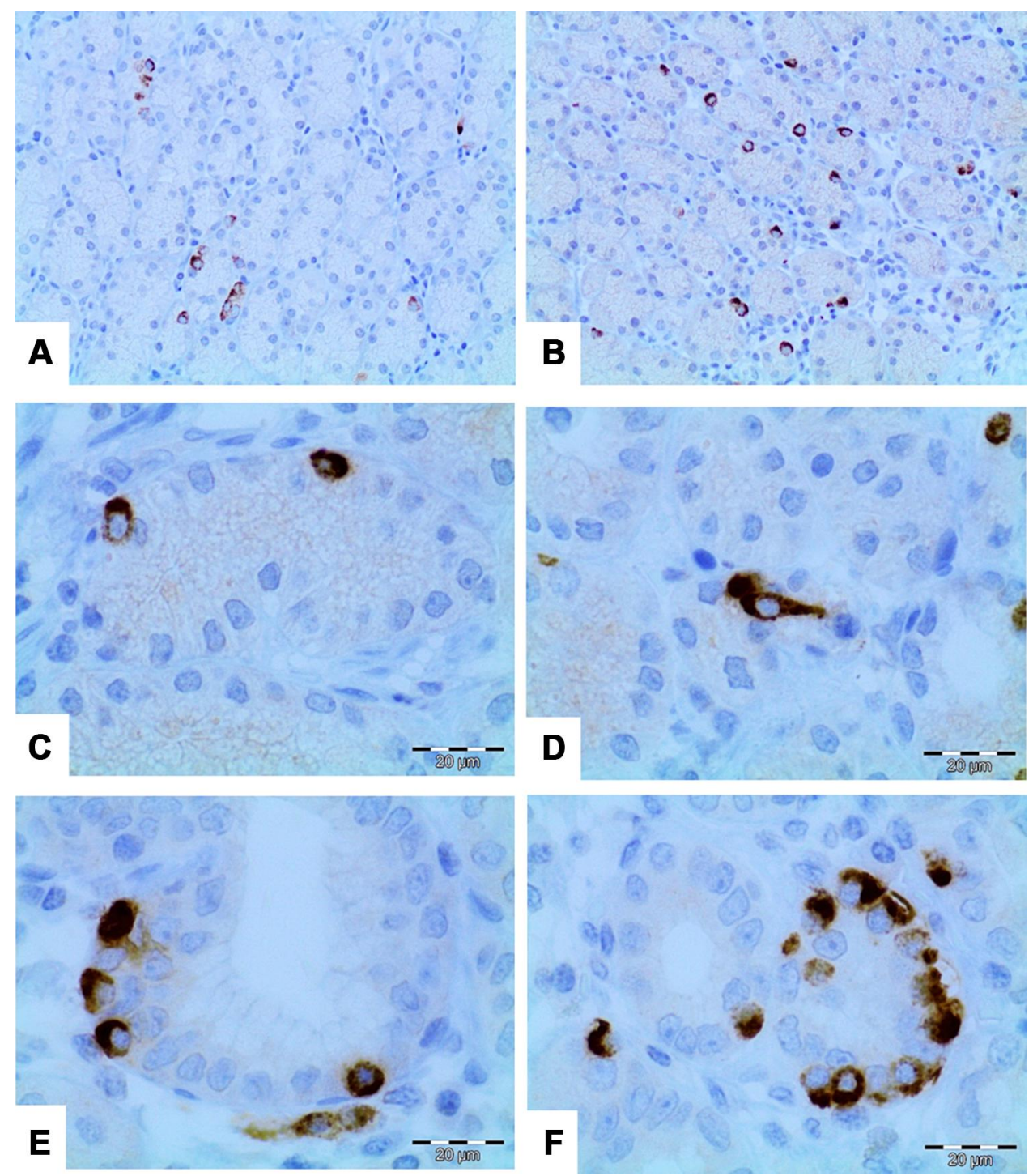

Figure I Immunohistochemical study for gastric ghrelin. Typical immunohistochemical characteristic showing cells located in the gastric glandular basal region with irregular distribution (A) and showing cells intermixed with mucous glands individually, some cluster of ghrelin cells are present (B). Characteristic immunoreactivity of ghrelin cells with granular cytoplasmic reactivity and cubic morphology (C). Fusiform morphology occasionally evidenced in ghrelin cells with characteristic granular cytoplasmic reactivity (D). (E) Positive ghrelin cells and presence of intestinal metaplasia. Note the absence of positive ghrelin cells in metaplasia intestinal metaplasia. (F) Ghrelin cells distributed in groups of 3 to 8 cells. This finding was the least evidenced in the study. (Direct increase 10X to 60X).

showed a significant difference between GhrC and gastric topography $(\mathrm{p}=0.004)$. In the antrum, the GhrC showed an irregular pattern in $90.16 \%$ of the samples, followed by the lower third $(6.56 \%)$ and in two-thirds of the epithelium $(3.28 \%)$. The body and the fundus showed a pattern like to the antrum, and the irregular pattern was the most frequent $(68.85 \% ; 70.49 \%)$ followed by the lower third $(21.31 \%$; $26.23 \%$ ) and the lower two-thirds $(9.84 \% ; 3.28 \%)$. (Figure 2 )

\section{GhrC, Gastric Topography and Gender}

A significant difference was found in the antrum between male/female patients and total GhrC $(\mathrm{p}=0.018)$ (Table 1). Male patients showed $132.94 \pm 116.3$ cells $/ 10 \mathrm{HPF}$ in the antrum, $230.19 \pm 130.3$ cells $/ 10 \mathrm{HPF}$ in the body, and $284.81 \pm 121.1$ cells/10HPF in the fundus. These results showed significant differences between GhrC and location $(p=0.001)$. No significant differences were observed between the presence of $\mathrm{GHrCs}$ and their location in female patients (Figure 3 and Table 2).

GhrC, gastric topography and comorbidities: A significant difference was found between the hypertensive and non-hypertensive groups and the number of GhrC (Table 1). In patients with $\mathrm{SAH}$, the number of cells in antrum is significantly lower than in the other gastric regions. In patients with no SAH, no significant differences were found (Figure 3 and Table 2). Instead, there is no difference 

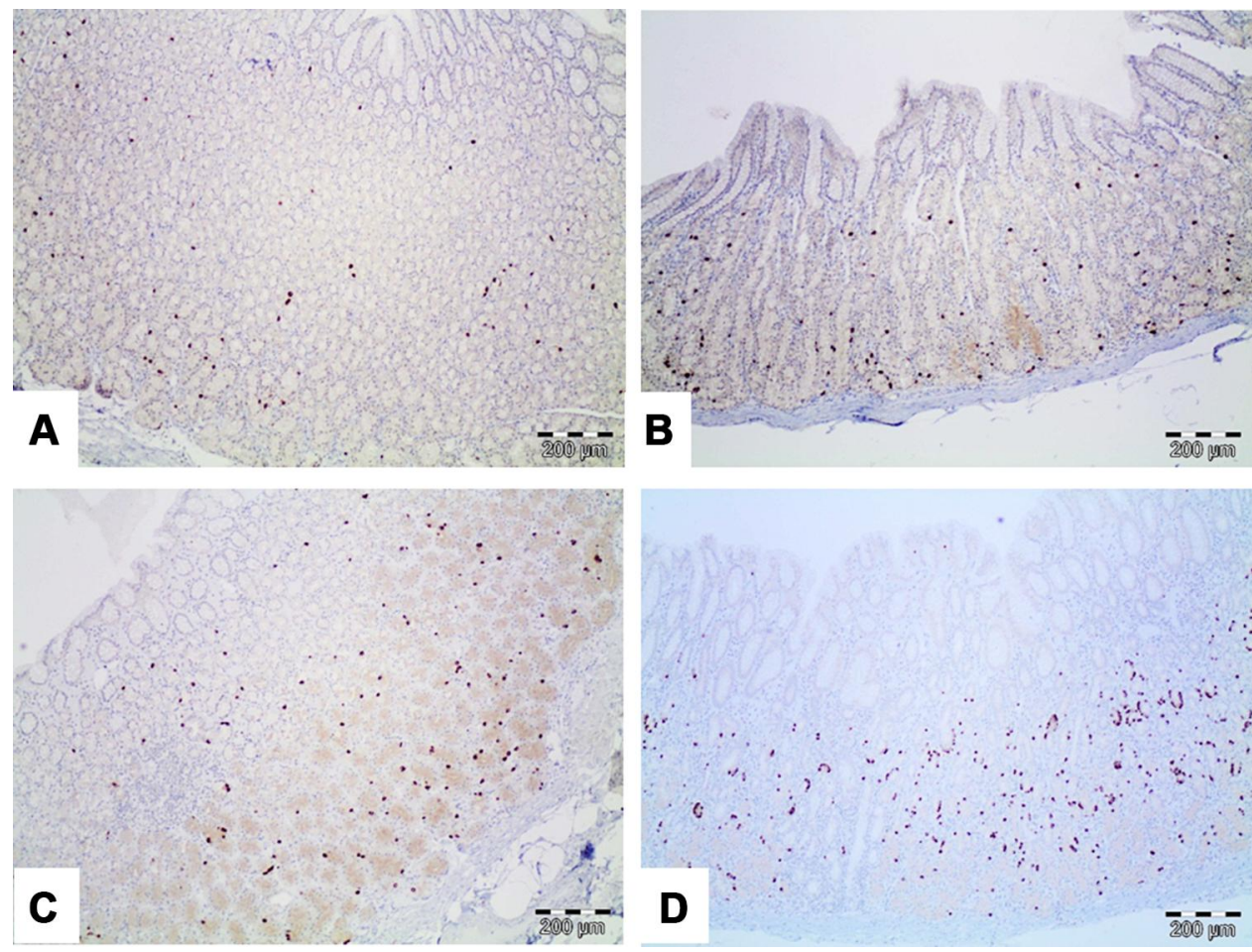

Figure 2 Immunohistochemical study for gastric cells with ghrelin positivity (A-D). Micrographs show different expression patterns of positive ghrelin cells within the gastric mucosa. (A) Irregular pattern. (B and C) Pattern of predominance in two thirds of the mucosa. (D) Pattern with a predominance in low third of the mucosa (direct increase $10 X)$.

between the diabetic and non-diabetic groups regarding the total presence of GhrCs; we also found no differences in the three areas in these patients (Tables 1 and 2). When we separated the gastric regions and gastritis or not, we

Table I Total Number of Gastric Ghrelin Expressing Cells (Cell/ IOHPF) by Gender and Comorbidities

\begin{tabular}{|c|c|c|}
\hline \multicolumn{3}{|c|}{ Gastric Ghrelin Expressing Cells (Cell/IOHPF) } \\
\hline \multirow{2}{*}{\begin{tabular}{|l} 
Total \\
Gender
\end{tabular}} & \multicolumn{2}{|l|}{$786.30 \pm 465.2$} \\
\hline & & p-value \\
\hline Male $26.2 \%(n=16)$ & $679.94 \pm 264.1$ & ns \\
\hline Female $73.8 \%(n=45)$ & $835.49 \pm 511.8$ & \\
\hline \multicolumn{3}{|l|}{ AHT } \\
\hline Yes $59 \%(n=36)$ & $706.19 \pm 446.7$ & 0.040 \\
\hline No $41 \%(n=25)$ & $896.75 \pm 485.6$ & \\
\hline \multicolumn{3}{|l|}{ T2D } \\
\hline Yes $36.1 \%(n=22)$ & $772.08 \pm 403.7$ & ns \\
\hline No $63.9 \%(n=39)$ & $811.50 \pm 567.8$ & \\
\hline \multicolumn{3}{|l|}{ Gastritis } \\
\hline Yes $88.5 \%(n=54)$ & $794.87 \pm 476.5$ & ns \\
\hline No $11.5 \%(n=7)$ & $720.14 \pm 391.6$ & \\
\hline
\end{tabular}

Note: $* \mathrm{P}<0.05$.

Abbreviations: AHT, arterial hypertension; T2D, Type 2 diabetes mellitus; HPF, high power field. observed that the differences observed in patients with hypertension and the male gender are also maintained significantly in the presence of gastritis (Figure 3 and Table 3).

\section{Plasma Ghrelin Levels}

Plasma ghrelin levels before surgery were $32.83 \pm 5.6 \mathrm{pg} /$ $\mathrm{mL}$ for $\mathrm{AG}$ and $207.4 \pm 39.3 \mathrm{pg} / \mathrm{mL}$ for DG. Six and 12 months after surgery, the levels of AG were $17.93 \pm 2.5 \mathrm{pg} /$ $\mathrm{mL}$ and $10.09 \pm 11.8 \mathrm{pg} / \mathrm{mL}$, respectively, and the levels of DG were $197.45 \pm 41.8 \mathrm{pg} / \mathrm{mL}$ and $188.84 \pm 52.3 \mathrm{pg} / \mathrm{mL}$, respectively. The statistical study showed a significant difference between AG values at the time of surgery, at 6 and 12 months $(p<0.05)$. There was a sustained decrease in the plasma levels of AG from surgery until 12 months later. Plasma levels of DG tended to decrease but no significant variation was observed (Figure 4). Plasmatic levels of AG and DG according to different variables are shown in Table 4. No differences between gender, BMI, or comorbidities have been found.

\section{Correlations Between Variables}

We observed a weak but significant positive correlation between the preoperative levels of DG and the GhrC in the body $\left(r^{2}=0.28\right)$. The body showed a significant positive 


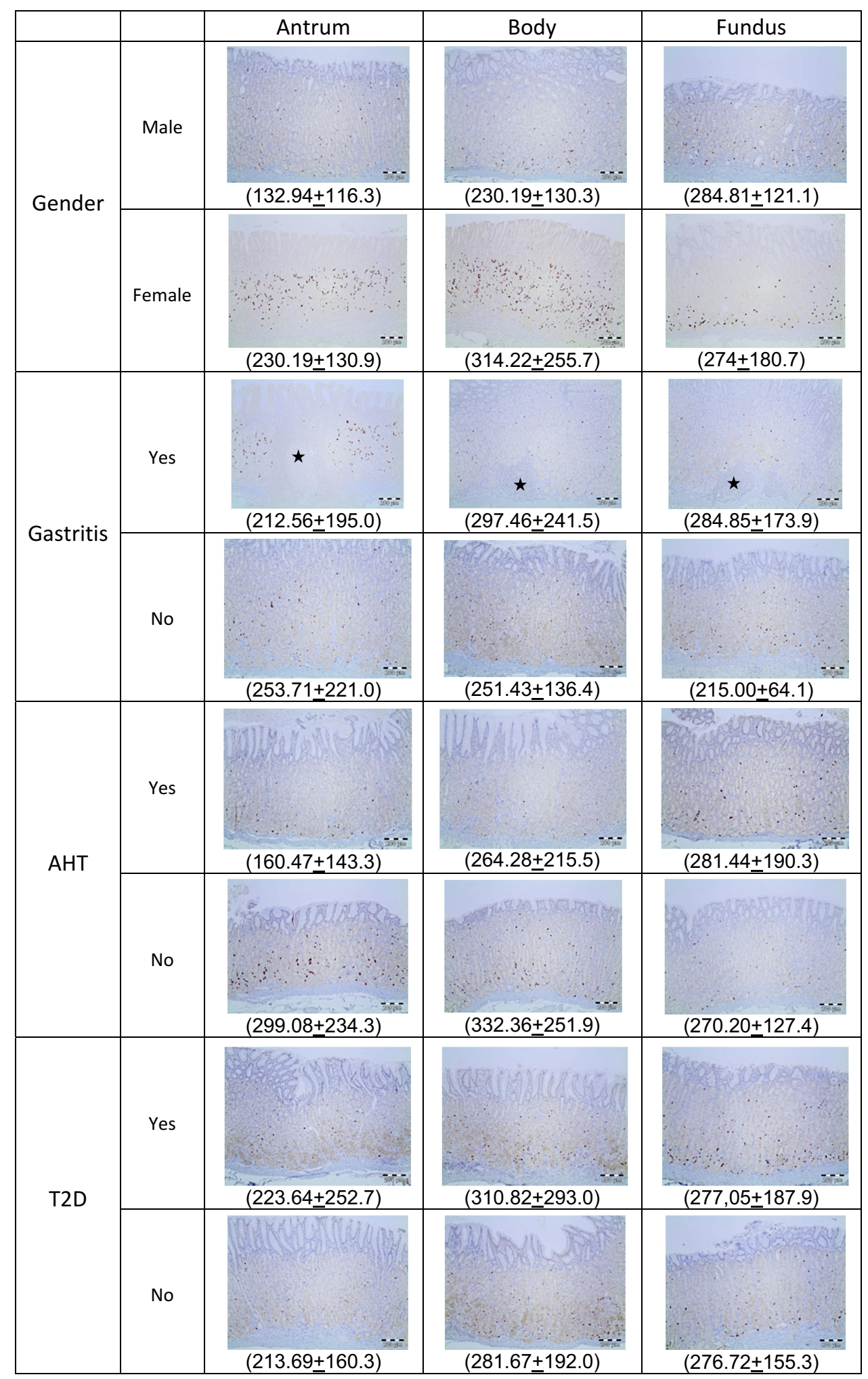

Figure 3 Immunohistochemical findings of positive gastric ghrelin cells in relation to gastric topography, gender and co-morbidities. In parentheses the average number of ghrelin cells shown. Microscopic images with direct magnification at 40x and diaminobenzidine staining (DAB).

correlation with the antrum cells $\left(r^{2}=0.59\right)$ and the fundus cells $\left(r^{2}=0.55\right)$. The rest of the correlations were not significant.

\section{Discussion}

In the present study, we determined the topographic distribution of the GhrC and their distribution pattern 
Table 2 Total Number of Gastric Ghrelin Expressing Cells (Cell/IOHPF) by Location, Gender, and Comorbidities

\begin{tabular}{|c|c|c|c|c|}
\hline & \multicolumn{4}{|c|}{ Gastric Ghrelin Expressing Cells (Cell/IOHPF) } \\
\hline & $\%(n)$ & Antrum & Body & Fundus \\
\hline Male & $26.2 \%(n=16)$ & $132.94 \pm \mid 16.3 *$ & $230.19 \pm 130.3$ & $284.81 \pm|2| .1$ \\
\hline Female & $73.8 \%(n=45)$ & $230.19+130.9$ & $314.22 \pm 255.7$ & $274 \pm 180.7$ \\
\hline AHT & $59 \%(n=36)$ & $160.47 \pm 143.3^{*}$ & $264.28 \pm 215.5$ & $281.44 \pm 190.3$ \\
\hline Non AHT & $41 \%(n=25)$ & $299.08 \pm 234.3$ & $332.36 \pm 251.9$ & $270.20 \pm 127.4$ \\
\hline T2D & $63.9 \%(n=39)$ & $223.64 \pm 252.7$ & $310.82 \pm 293.0$ & $277,05 \pm 187.9$ \\
\hline Non T2D & $36.1 \%(n=22)$ & $213.69 \pm 160.3$ & $281.67 \pm 192.0$ & $276.72 \pm 155.3$ \\
\hline Gastritis & $88.5 \%(n=54)$ & $212.56 \pm 195.0$ & $297.46 \pm 241.5$ & $284.85 \pm 173.9$ \\
\hline Non-gastritis & $11.5 \%(n=7)$ & $253.71 \pm 221.0$ & $251.43 \pm 136.4$ & $215.00 \pm 64.1$ \\
\hline $\mathrm{BMl}<50 \mathrm{~kg} / \mathrm{m} 2$ & $49,1 \%(n=30)$ & $233,93 \pm 234, I$ & $323,52 \pm 292,3$ & $296,83 \pm 192,7$ \\
\hline $\mathrm{BMI}>50 \mathrm{~kg} / \mathrm{m} 2$ & $50,9 \%(n=31)$ & $202,19 \pm 157,5$ & $263,78 \pm 157,6$ & $258,72 \pm 138,8$ \\
\hline
\end{tabular}

Note: $* \mathrm{P}<0.05$ between groups of patients.

Abbreviations: AHT, arterial hypertension; T2D, Type 2 diabetes mellitus; HPF, high power field.

Table 3 Total Number of Gastric Ghrelin Expressing Cells (Cell/IOHPF) Related to Gastritis, by Location, Gender, and Comorbidities

\begin{tabular}{|c|c|c|c|c|}
\hline \multicolumn{5}{|c|}{ Gastric Ghrelin Expressing Cells (Cell/IOHPF) } \\
\hline \multicolumn{3}{|c|}{ Male $26.2 \%(n=16)$} & \multicolumn{2}{|l|}{ Female $73.8 \%(n=45)$} \\
\hline & Gastritis - $18.7 \%(n=3)$ & Gastritis + $81.4 \%(n=13)$ & Gastritis $-8.9 \%(n=4)$ & Gastritis + $91.1 \%(n=41)$ \\
\hline Antrum & $243.00 \pm 257.2$ & $107.54 \pm 46.4^{*}$ & $261.75 \pm 230.9$ & $245.85 \pm 212.2$ \\
\hline Body & $197.33 \pm \mid 48.1$ & $237.77 \pm|3| .3$ & $292.00 \pm 132.2$ & $316.39 \pm 265.7$ \\
\hline Fundus & $209.67 \pm 63.0$ & $302.15 \pm 126.2$ & $219.00 \pm 74.3$ & $279.37 \pm 187.6$ \\
\hline \multicolumn{3}{|c|}{ AHT $59 \%(n=36)$} & \multicolumn{2}{|l|}{ Non AHT 4 I\% $(n=25)$} \\
\hline & $\begin{array}{l}\text { Gastritis - } \\
16.6 \%(n=6)\end{array}$ & $\begin{array}{l}\text { Gastritis + } \\
83.4 \%(n=30)\end{array}$ & $\begin{array}{l}\text { Gastritis - } \\
4 \%(n=1)\end{array}$ & $\begin{array}{l}\text { Gastritis + } \\
96 \%(n=24)\end{array}$ \\
\hline Antrum & $266.83 \pm 239.0$ & $139.20 \pm 110.0 *$ & 175 & $304.25 \pm 237.9$ \\
\hline Body & $241.67 \pm 146.7$ & $268.80 \pm 228.5$ & 310 & $333.29 \pm 257.2$ \\
\hline Fundus & $208.00 \pm 67.2$ & $296.13 \pm 203.9$ & 257 & $270.75 \pm \mid 30.1$ \\
\hline \multicolumn{3}{|c|}{ T2D $63.9 \%(n=39)$} & \multicolumn{2}{|l|}{ Non T2D 36.1\% $(n=22)$} \\
\hline & $\begin{array}{l}\text { Gastritis - } \\
10.2 \%(n=4)\end{array}$ & $\begin{array}{l}\text { Gastritis + } \\
89.8 \%(n=35)\end{array}$ & $\begin{array}{l}\text { Gastritis - } \\
\text { I3.6\% (n=3) }\end{array}$ & $\begin{array}{l}\text { Gastritis + } \\
86.4 \%(n=19)\end{array}$ \\
\hline Antrum & $268.67 \pm 292.3$ & $216.53 \pm 254.1$ & $242.50 \pm 200.7$ & $210.40 \pm 158.3$ \\
\hline Body & $223.67 \pm 205.3$ & $324.58 \pm 306.6$ & $272.25 \pm 88.1$ & $282.74 \pm 201.3$ \\
\hline Fundus & $182.67 \pm 93.4$ & $291.95 \pm 196.3$ & $239.67 \pm 23.7$ & $281.00 \pm 163.5$ \\
\hline
\end{tabular}

Note: $* \mathrm{P}<0.05$.

Abbreviations: AHT, arterial hypertension; T2D, Type 2 diabetes mellitus; HPF, high power field.

within the mucosa in the different gastric regions from the surgical pieces resulting from LSG. Our results show a predominantly irregular cell pattern within the gastric mucosa. In addition, the cells are present in all regions of the gastric mucosa, with a greater number in the body and the fundus, and with a considerable amount in the antral region. Goitein et $\mathrm{al}^{19}$ published similar findings, although in our results we did not find significant differences between the body and the fundus. The body and fundus appear to be the main regions with GhrCs of patients with morbid obesity. In addition, the presence of cells in the antrum can help define the role of this area in obesity and certainly influence the surgical strategy to be followed, especially in the case of LSG. ${ }^{20}$ In our case, the initial section at $3 \mathrm{~cm}$ from the pylorus, is enough to have a representative sample of antrum; shorter distances 


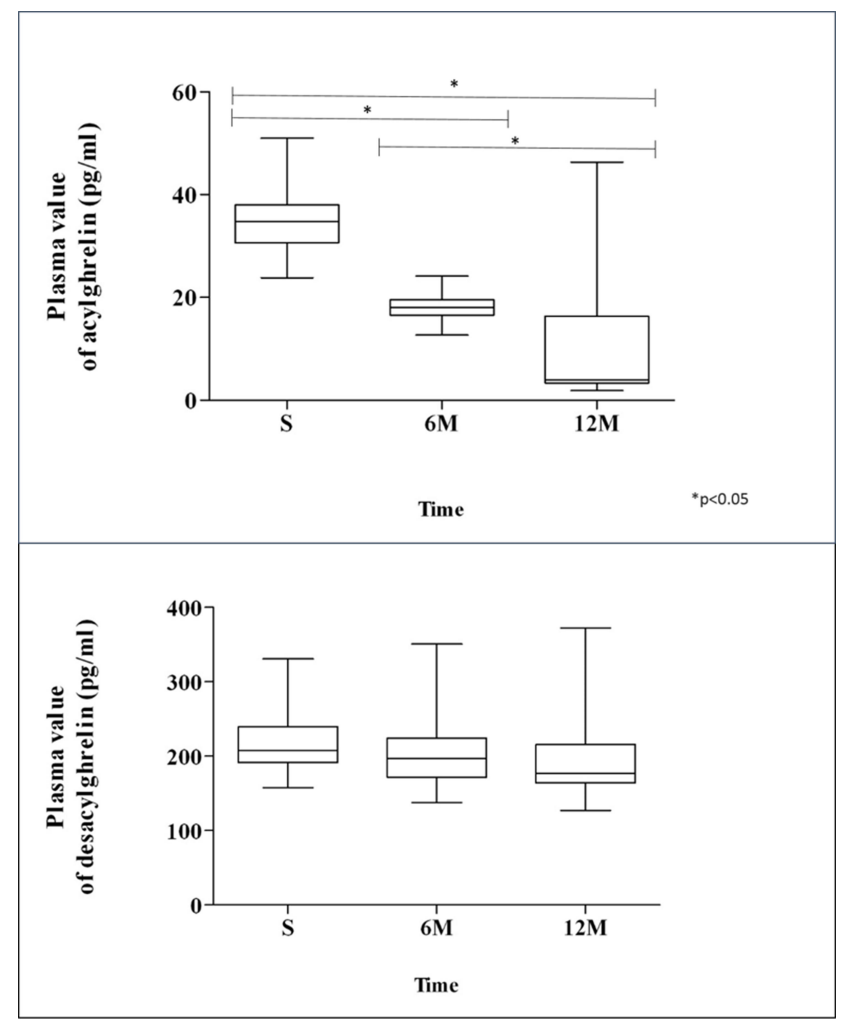

Figure 4 Plasmatic values of desacylghrelin and acylghrelin. Abbreviations: S, surgery; 6M, 6 months; $12 \mathrm{M}, 12$ months.

are not recommended (could produce a semi-obstruction, affecting the gastric emptying). ${ }^{21}$

Another histopathological finding of the present study is the presence of gastritis in $88.5 \%$ of the patients, mostly pangastritis, as well as $18 \%$ Helicobacter pylori (HP) positivity (pre-surgery). Some studies have shown similar results in relation to the presence of gastritis in patients with obesity. $^{22-24}$ In addition to the alterations that occur in the gastric mucosa caused by inflammation, the accumulation of molecules related to this process, such as interleukins and chemokines in the mucosa, has also been correlated with different additional effects, such as influencing the severity of Non-Alcoholic Fatty Liver Disease (NAFLD). But the relationship between HP infection and obesity still needs to be studied further; a lower prevalence of HP infection has been reported in obese patients than in the general population $^{25}$ while other studies have reported the opposite. $^{26}$ The significant increase in body mass index (BMI) observed after the eradication of HP in several studies reveals a possible inverse correlation between HP infection and obesity. ${ }^{27,28}$ Regarding its relationship with ghrelin, a recent work with patients with peptic ulcer shows that ghrelin plasma levels (AG and DG) are significantly lower
Table 4 AcylGhrelin and DesacylGhrelin Plasmatic Values Related to Gender and Comorbidities

\begin{tabular}{|c|c|c|c|}
\hline & $\mathbf{N}$ & $\begin{array}{l}\text { Acyl Ghrelin } \\
\mathrm{pg} / \mathrm{mL}\end{array}$ & $\begin{array}{l}\text { Desacyl Ghrelin } \\
\mathrm{pg} / \mathrm{mL}\end{array}$ \\
\hline $\begin{array}{c}\text { Gender } \\
\text { Male } \\
\text { Female } \\
p \text { value }\end{array}$ & $\begin{array}{l}16 \\
45\end{array}$ & $\begin{array}{l}33,72 \pm 4,77 \\
34.84 \pm 5,98 \\
\text { ns }\end{array}$ & $\begin{array}{l}217,16 \pm 29,99 \\
218,55 \pm 42,71 \\
\text { ns }\end{array}$ \\
\hline $\begin{array}{l}\text { Age } \\
\qquad \begin{array}{l}<50 \text { years } \\
>50 \text { years } \\
p \text { value }\end{array}\end{array}$ & $\begin{array}{l}30 \\
31\end{array}$ & $\begin{array}{l}34,24 \pm 5,22 \\
34.82 \pm 6,13 \\
\text { ns }\end{array}$ & $\begin{array}{l}208,25 \pm 34,60 \\
228,08 \pm 41,86 \\
\text { ns }\end{array}$ \\
\hline $\begin{array}{l}\text { BMI } \\
\qquad \begin{array}{l}<0 \mathrm{~kg} / \mathrm{m}^{2} \\
>50 \mathrm{~kg} / \mathrm{m}^{2} \\
p \text { value }\end{array}\end{array}$ & $\begin{array}{l}30 \\
31\end{array}$ & $\begin{array}{l}35,38 \pm 4,91 \\
33.74 \pm 6,24 \\
\text { ns }\end{array}$ & $\begin{array}{l}231,26 \pm 39,62 \\
205,95 \pm 35,53 \\
\text { ns }\end{array}$ \\
\hline $\begin{array}{l}\text { DM2 } \\
\text { Yes } \\
\text { No } \\
p \text { value }\end{array}$ & $\begin{array}{l}22 \\
39\end{array}$ & $\begin{array}{l}34,47 \pm 5,86 \\
34.63 \pm 5,42 \\
\text { ns }\end{array}$ & $\begin{array}{l}212,23 \pm 37,83 \\
227,89 \pm 40,74 \\
n s\end{array}$ \\
\hline $\begin{array}{l}\text { AHT } \\
\text { Yes } \\
\text { No } \\
p \text { value }\end{array}$ & $\begin{array}{l}36 \\
25\end{array}$ & $\begin{array}{l}34,30 \pm 6,02 \\
34.88 \pm 5,15 \\
\text { ns }\end{array}$ & $\begin{array}{l}222,97 \pm 41,54 \\
210,85 \pm 35,41 \\
\text { ns }\end{array}$ \\
\hline
\end{tabular}

Abbreviations: AHT, arterial hypertension; T2D, Type 2 diabetes mellitus; ns, not significant.

in HP positive patients than in HP patients. ${ }^{29}$ Similarly, HP infection has also been associated with a decrease in the gastric expression of leptin and ghrelin and it seems that it can protect from large intakes in situations of obesity. ${ }^{30}$ Therefore, it seems necessary to explore the true association between HP infection, obesity, and other factors that influence this relationship, since ghrelin, leptin, and the microbiota could play a fundamental role. ${ }^{31}$

We did not find statistically significant differences between cell count in the two sexes, unlike studies published about healthy patients in which the number of cells is higher in females. ${ }^{16,24}$ Even so, in absolute numbers we observed a greater number of cells in females than in males, and when we analyzed cell count by topographic areas, we observed that in men, this difference is significant in the antrum and in the patients with a chronic gastritis. The subgroup of patients with SAH follows the same pattern. In this group, we found a significantly lower number of GhrC than in nonhypertensive patients. This difference again is due to the number of cells in the antrum and chronic gastritis. In this sense, an inverse correlation has been reported between 
GhrC and the degree of chronic gastritis in patients with gastric cancer. ${ }^{32}$ However, finding a lower number of cells in hypertensive patients may be justified by the vasodilator and cardiovascular protective action of ghrelin.,33 Ghrelin produces different effects on the cardiovascular system, mediated in part by Growth Hormone and reninangiotensin system blockade, although the exact mechanisms are still unknown. Among its effects, we find a decrease in blood pressure, peripheral resistance, and also stimulates angiogenesis. If the number of Ghrelin-producing cells is lower, their plasma concentration will be affected, which can contribute to maintaining high blood pressure. ${ }^{34}$ Furthermore, the male gender also shows this decrease in cells in the antrum, and it is known that high blood pressure as part of the metabolic syndrome is also more prevalent in the male gender. Prevalence studies in this regard are necessary to correlate both variables. Therefore, these factors imply the antrum as a key point to consider in the surgical therapeutic approach. ${ }^{20}$

Regarding the variation of the plasma levels of ghrelin isoforms, a significant and sustained decrease in the AG values during the 12 months after surgery was observed as in other studies. ${ }^{35}$ The values of DG also showed a tendency to an initial decrease 6 months after surgery; however, later, the plasma values showed no variation. The AG is attributed to have an orexigenic effect and is determinant in the pathogenesis of obesity, while DG is attributed actions such as promoting the differentiation of skeletal muscle cells, preventing muscle atrophy, exerting a cardioprotective effect on endothelial cells and cardiomyocytes. ${ }^{34,35}$ The decrease in AG after surgery in this regard is fundamental; however, the maintenance of DG in plasma may be due to the extragastric synthesis, ${ }^{35-37}$ in response to the surgery of the stomach. ${ }^{38}$ Therefore, it is essential that plasma values after surgery are reported in both isoforms and that even the $\mathrm{AG}$ can be a biomarker of the surgical. The inhibitors of the GOAT enzyme could also play a role in maintaining the balance between the two isoforms. ${ }^{39}$ In this sense, this work presents as a limitation the non-immunohistochemical detection of GOAT; studies focusing on metabolomic activity of this areas quantifying its metabolic spectrum using MALDI techniques or similar are undoubtedly needed.

\section{Conclusion}

We have demonstrated a significant effect on ghrelin levels isoforms after surgery. This reduction could be explained by the fact that gastric-producing ghrelin cells are removed from the antrum, body, and fundus. In most of the patients (women), no differences were found in the topography of ghrelin cells (not as in the male gender). The primary reduction in AG plasma levels shown in our study gives details about topography of ghrelin cells. The present data could provide novel insights into the role of gastric Ghrelin and its relationship with obesity.

\section{Acknowledgments}

The technical assistance of Carmen Guilarte and Carolina Zorrilla is acknowledged.

\section{Funding}

This study was funded by the "Carlos III Research Institute"/Ministry of Economy and Competitiveness (registration number PI 11/02332), Spain.

\section{Disclosure}

The authors report no conflicts of interest in this work.

\section{References}

1. Swinburn B, Kraak V, Allender S, et al. The global syndemic of obesity, undernutrition, and climate change: the lancet commission report. Lancet. 2019;393:791-846. doi:10.1016/S0140-6736(18) 32822-8

2. Bray G, Frühbeck G, Ryan D, et al. Management of obesity. Lancet. 2016;387:1947-1956. doi:10.1016/S0140-6736(16)00271-3

3. Kojima M, Hosoda H, Date Y, et al. Ghrelin is a growth-hormonereleasing acylated peptide from stomach. Nature. 1999;402:656-660. doi: $10.1038 / 45230$

4. Müller T, Nogueiras R, Andermann M, et al. Ghrelin. Mol Metab. 2015;4:437-460. doi:10.1016/j.molmet.2015.03.005

5. Sönmez M, Karabulut D, Gunduz Y, Dundar M. The effects of long-term diabetes on ghrelin expression in rat stomachs. Adv Clin Exp Med. 2015;24:401-407. doi:10.17219/acem/43723

6. Virdis A, Lerman LO, Regoli F, et al. Human ghrelin: a gastric hormone with cardiovascular properties. Curr Pharm Des. 2016;22:52-58. doi:10.2174/1381612822666151119144458

7. Sjöström L, Peltonen M, Jacobson P, et al. Bariatric surgery and long-term cardiovascular events. JAMA. 2012;307:56-65. doi:10.10 01/jama.2011.1914

8. Hosoda H, Kojima M, Matsuo H, et al. Ghrelin and des-acyl ghrelin: two major forms of rat ghrelin peptide in gastrointestinal tissue. Biochem Biophys Res Commun. 2000;279:909-913. doi:10.1006/ bbrc.2000.4039

9. De Vriese C, Gregoire F, Lema-Kisoka R, et al. Ghrelin degradation by serum and tissue homogenates: identification of the cleavage sites. Endocrinology. 2004;145:4997-5005. doi:10.1210/en.2004-0569

10. Akamizu T, Takaya K, Irako T, et al. Pharmacokinetics, safety, and endocrine and appetite effects of ghrelin administration young healthy subjects. Eur J Endocrinol. 2004;150:447-455. doi:10.1530/ eje. 0.1500447

11. Nakazato M, Murakami N, Date Y, et al. A role for ghrelin in the central regulation of feeding. Nature. 2001;409:194-198. doi:10.10 38/35051587

12. Barnett B, Hwang Y, Taylor M, et al. Glucose and weight control in mice with a designed ghrelin O-acyltransferase inhibitor. Science. 2010;330:1689-1692. doi:10.1126/science.1196154 
13. Holst J, Madsbad S, Bojsen-Møller K, et al. Mechanisms in bariatric surgery: gut hormones, diabetes resolution, and weight loss. Surg Obes Relat Dis. 2018;14:708-714. doi:10.1016/j.soard.2018.03.003

14. Anderson B, Switzer N, Almamar A, et al. The impact of laparoscopic sleeve gastrectomy on plasma ghrelin levels: a systematic review. Obes Surg. 2013;23:1476-1480. doi:10.1007/s11695-0130999-7

15. Angrisani L, Santonicola A, Iovino P, et al. Bariatric surgery and endoluminal procedures: IFSO worldwide survey 2016. Obes Surg. 2018;28:3783-3794. doi:10.1007/s11695-018-3450-2

16. Kasacka I, Arciszewski M, Janiuk I, et al. Comparative evaluation of gastric ghrelin cells and levels of hormone in the serum of healthy women and men. J Biol Regul Homeost Agents. 2013;27:69-78.

17. Angrisani L, Vitiello A, Ferraro L. Comment on: two-stage approach is still the gold standard for super-super obese patients (SSO) undergoing bariatric surgery. Surg Obes Relat Dis. 2019;15:33-35. doi:10.1016/j.soard.2018.11.011

18. Rugge M, Genta M. Staging and grading of chronic gastritis. Hum Pathol. 2015;36:228. doi:10.1016/j.humpath.2004.12.008

19. Goitein D, Lederfein D, Tzioni R, et al. Mapping of ghrelin gene expression and cell distribution in the stomach of morbidly obese patients - a possible guide for efficient sleeve gastrectomy construction. Obes Surg. 2012;22:617-622. doi:10.1007/s11695011-0585-9

20. Vives M, Molina A, Danús M, et al. Analysis of gastric physiology after laparoscopic sleeve gastrectomy (LSG) with or without antral preservation in relation to metabolic response: a randomised study. Obes Surg. 2017;27:2836-2844. doi:10.1007/s11695-017-2700-z

21. Gagner M. Faster gastric emptying after laparoscopic sleeve gastrectomy. Obes Surg. 2010;20:964-965. doi:10.1007/s11695-0100086-2

22. Dietz J, Ulbrich-Kulcynski JM, Souto K, et al. Prevalence of upper digestive endoscopy and gastric histopathology findings in morbidly obese patients. Arq Gastroenterol. 2012;49:52-55. doi:10.1590/ S0004-28032012000100009

23. Onzi T, d'Acampora A, de Araújo F, et al. Gastric histopathology in laparoscopic sleeve gastrectomy: pre- and post-operative comparison. Obes Surg. 2014;24:371-376. doi:10.1007/s11695-013-1107-8

24. Musella M, Di Capua F, D'Armiento M, et al. No difference in ghrelin-producing cell expression in obese versus non-obese stomach: a prospective histopathological case-control study. Obes Surg. 2018;28:3604-3610. doi:10.1007/s11695-018-3401-y

25. Carabotti M, D'Ercole C, Iossa A, et al. Helicobacter pylori infection in obesity and its clinical outcome after bariatric surgery. World J Gastroenterol. 2014;20:647-653. doi:10.3748/wjg.v20.i3.647

26. Arslan E, Atilgan H, Yavaşoğlu I. The prevalence of Helicobacter pylori in obese subjects. Eur J Intern Med. 2009;20:695-697. doi:10.1016/j.ejim.2009.07.013
27. Dhurandhar N, Bailey D, Thomas D. Interaction of obesity and infections. Obes Rev. 2015;16:1017-1029. doi:10.1111/obr.12320

28. Lane J, Murray J, Harvey I, et al. Randomised clinical trial: Helicobacter pylori eradication is associated with a significantly increased body mass index in a placebo-controlled study. Aliment Pharmacol Ther. 2011;33:922-929. doi:10.1111/j.1365-2036.2011. 04610.x

29. Kasai C, Sugimoto K, Moritani I, et al. Changes in plasma ghrelin and leptin levels in patients with peptic ulcer and gastritis following eradication of Helicobacter pylori infection. BMC Gastroenterol. 2016;16:119. doi:10.1186/s12876-016-0532-2

30. Xu M, Liu L, Yuan B, et al. Association of obesity with Helicobacter pylori infection: a retrospective study. World $J$ Gastroenterol. 2017;23:2750-2756. doi:10.3748/wjg.v23.i15.2750

31. Yanagi H, Tsuda A, Matsushima M, et al. Changes in the gut microbiota composition and the plasma ghrelin level in patients with Helicobacter pylori-infected patients with eradication therapy. BMJ Open Gastroenterol. 2017;4:e000182. doi:10.1136/bmjgast-2017-000182.

32. Takiguchi S, Adachi S, Yamamoto K, et al. Mapping analysis of ghrelin producing cells in the human stomach associated with chronic gastritis and early cancers. Dig Dis Sci. 2012;57:1238-1246. doi:10.1007/s10620-011-1986-2

33. Dimitriadisc E, Daskalakis M, Kampa M, et al. Alterations in gut hormones after laparoscopic sleeve gastrectomy: a prospective clinical and laboratory investigational study. Ann Surg. 2013;257:647-654. doi:10.1097/SLA.0b013e31826e1846

34. Tuero C, Valenti V, Rotellar F, et al. Revisiting the ghrelin changes following bariatric and metabolic surgery. Obes Surg. 2020;30:276380. doi:10.1007/s11695-020-04601-5

35. Date Y, Nakazato M, Hashiguchi S, et al. Ghrelin is present in pancreatic alpha-cells of humans and rats and stimulates insulin secretion. Diabetes. 2002;51:124-129. doi:10.2337/diabetes.51.1.124

36. Date Y, Kojima M, Hosoda H, et al. Ghrelin, a novel growth hormone-releasing peptide, is synthesized in a distinct endocrine cell type in the gastrointestinal tracts of rats and humans. Endocrinology. 2000;141:4255-4261. doi:10.1210/endo.141.11.7757

37. Mori K1, Yoshimoto A, Takaya K, et al. Kidney produces a novel acylated peptide, ghrelin. FEBS Lett. 2000;486:213-216. doi:10.1016/S0014-5793(00)02308-5

38. Sabench F, Hernández M, Feliu A, et al. Influence of sleeve gastrectomy on several experimental models of obesity: metabolic and hormonal implications. Obes Surg. 2008;18:97-108. doi:10.1007/ s11695-007-9351-4

39. Yoneyama-Hirozane M, Deguchi K, Hirakawa T, et al. Identification and characterization of a new series of ghrelin O-acyl transferase inhibitors. SLAS Discov. 2018;23:154-163. doi:10.1177/24725552 17727097

\section{Publish your work in this journal}

Diabetes, Metabolic Syndrome and Obesity: Targets and Therapy is an international, peer-reviewed open-access journal committed to the rapid publication of the latest laboratory and clinical findings in the fields of diabetes, metabolic syndrome and obesity research. Original research, review, case reports, hypothesis formation, expert opinion and commentaries are all considered for publication. The manuscript management system is completely online and includes a very quick and fair peer-review system, which is all easy to use. Visit http://www.dovepress.com/testimonials.php to read real quotes from published authors. 